\title{
解説（2006 年度日本食品工学会産学官連携賞）
}

\section{コーヒー豆由来のマンノオリゴ糖の食品への高度応用}

\author{
藤井繁佳 ${ }^{\dagger}$, 浅野一朗，尾崎和人，熊王俊男 \\ 味の素ゼネラルフーヅ株式会社＼cjkstart商品・技術開発研究所
}

\section{Higher Value Added Food Product Development Using Mannooligosaccharides from Coffee Bean}

\author{
Shigeyoshi FUJII ${ }^{\dagger}$, Ichiro ASANO, Kazuto OZAKI, and Toshio KUMAO \\ $R \& D$ and Engineering Dept., Ajinomoto General Foods, INC., \\ Sanken Bldg., 3-25-1 Hyakunin-cho, Shinjuku-ku, Tokyo 169-0073, Japan
}

\begin{abstract}
Coffee is a popular beverage worldwide. Recently, many epidemiological studies suggest that coffee may play a preventative role in various diseases. There has been increasing interest in the health benefits of coffee. Coffee contains several bioactive compounds, which are known to affect human body chemistry. Among them, we focused on mannooligosaccharides (MOS) extracted by thermal hydrolysis from spent coffee grounds. MOS from coffee are composed of mannose, which is known to have physiological functions such as the prevention of Salmonella infection. MOS are also expected to have various other types of physiological functions. However, no prior research is available regarding the functionality of MOS from coffee. First, we demonstrated the prebiotic effect of MOS in a human intervention study after the confirmation of this effect in vitro and in an animal feeding study. Next, we confirmed the fat reduction effect of MOS by studying the inhibition of intestinal absorption of dietary fat in animals and in a human clinical study. These findings were applied to our coffee products containing MOS. These products have been certified as Foods for Specified Health Use (FOSHU) and commercially launched.
\end{abstract}

Keywords: mannooligosaccharides, prebiotics, body fat reduction, Food for Specified Health Use (FOSHU)

\section{はじめに}

コーヒー産業において, 完全に抽出されていないコー ヒ一粕は, 一部堆肥原料などに利用 [1] されてはいたが, そのほとんどは燃料として焼却されるか，あるいは産 業廃棄物として処理されていた。しかしながら，コー ヒ一粕中には未利用の有効資源が相当量含まれている. 環境問題が世界的規模で取り沙汰されている今日，自 然の恵みであるコーヒーを余すことなく高度に食品と して応用することは，コーヒーメーカーである我々の 社会的な使命であると考えた。 また，近年，嗜好品の 代表であるコーヒ一は，その生理作用打よび健康効果 が注目されており，カフェイン，クロロゲン酸拉よび

(受付 2007 年 11 月 14 日, 受理 2007 年 11 月 27 日) × 169-0073 東京都新宿区百人町 3-25-1 サンケンビル Fax: 03-5338-6713, E-mail: Shigeyoshi_Fujii@agf.co.jp
ナイアシンなどの特定成分について，さまざまな機能 性研究が報告されていることから，へルスサイエンス の面からも注目を集めている [2].

このような背景の中，我々は，コーヒ一粕中に多量 に含まれているマンナンを熱加水分解することによっ て得られるマンノオリゴ糖に着目した，感染症予防な どで注目されているマンノースを構成糖とするマンノ オリゴ糖は，様々な機能性が期待されていたが，これ までほとんど研究されていなかった。 そこで新たなコー ヒ一由来機能性成分としての可能性を有するマンノオ リゴ糖の有効性について検証を開始した。

\section{1. マンノォリゴ糖とは}


防作用がある単糖である [3]. マンノオリゴ糖は, 構成 するマンノースの結合様式の違いにより $\alpha$ 型および $\beta$ 型 の 2 種類に分類される.

$\alpha$ 型は主に酵母由来であり, 飼料への応用研究が進め られている. 特に単糖であるマンノースと違い, 腸内 細菌に資化されにくい上，病原菌の定着を抑制する機 能の点から, 抗生物質代替素材として脚光を浴びてい る [4]. $\beta$ 型では, 主に植物由来でガラクトマンノオリ ゴ糖，グルコマンノオリゴ糖およびマンノオリゴ糖が 知られている.ガラクトマンノオリゴ糖およびグルコ マンノオリゴ糖については, ビフィズス菌の増殖活性 などの機能評価についての研究が行われている $[5,6]$. マンノオリゴ糖としては，コプラミール由来のものが 知られているが, 飼料への応用が中心に研究されてお り $[7,8]$, 食品への応用例は報告されて抢らず，その機 能性ついても未解明であった。

\section{2. コーヒー豆由来マンノオリゴ糖の製造方法}

コーヒー豆由来のマンノオリゴ糖は，完全に抽出し きっていない焙煎粉砕コーヒー豆，いわゆるコーヒー 抽出粕中に多量に含まれているマンナンが原料となる. コーヒー抽出粕中からのマンノオリゴ糖の抽出は, い ろいろな方法で研究が進められており, 現在のところ, 熱加水分解, 酸加水分解抢よび酵素加水分解などが報 告されている.この中で最もよく研究されているのは, マンナン分解醅素を用いた䣼素抽出法である [9-11]. しかし，この方法は，大量生産の観点で収率打よびコ ストの面で難点があり, 産業レべルまでの応用はされ ていないのが実情である，一方，熱加水分解法は，一 度に大量の処理ができるため, 現在のところ最も有力 な方法であると考えられている [12]. 粉砕したコーヒー 粕に水を加えてスラリ一調製した後, 管式熱栓流反応 器において高圧蒸気とともに加水分解する。できたス ラリーから，水溶性画分を分離して加水分解物を得た 後, 活性炭により脱色およびイオン交換により脱塩を 行う。この方法で得られるマンノオリゴ糖は，2-10 糖 類のオリゴ糖である.

\section{3. コーヒー豆由来マンノォリゴ糖の特性}

コーヒー豆由来マンノオリゴ糖は， $\beta$ マンノオリゴ糖 であり，マンノースが直鎖状に $\beta 1,4$ マンノシド結合し た形態をしている。一般に 2 糖類から 10 糖類までのオ リゴ糖を総称してマンノオリゴ糖とする事としている (Fig.1).

マンノオリゴ糖を食品素材として幅広く応用するた めには，素材のもつ性質を調べる必要がある。 そこで 我々は，マンノオリゴ糖の特性について検証した。 そ

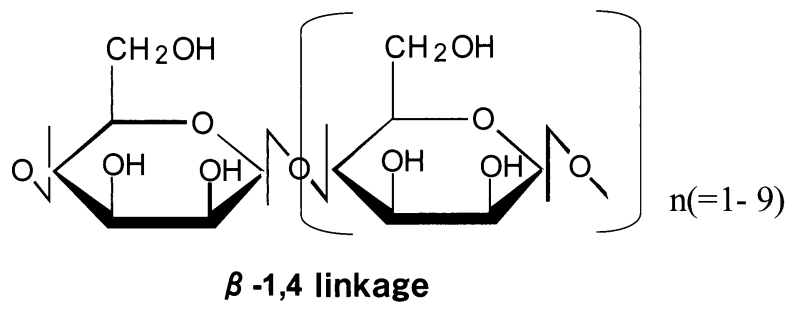

Fig. 1 Composition of mannooligosacchairdes from coffee mannan.

の結果，甘味はショ糖 100 に対して約 20 であり,ごく わずかに苦味のある爽やかな甘さを有していた。また 既知のアスパルテームなどの甘味料あるいはコーヒー その他の飲食物に含有させることにより呈味改善効果

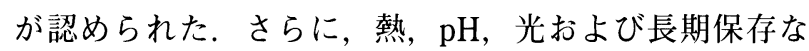
どに対してほとんど分解を打こさず，高い安定性を示 した。これらの結果により，マンノオリゴ糖は，味お よび品質を変えることなく, 幅広く食品に応用可能で あることが明らかとなった [13].

\section{4. 整 腸 効 果}

(1) マンノオリゴ糖の消化性

生体内に打ける代謝状態を明らかにするために， $\alpha$ ア ミラーゼ, 胃液, 膵液および小腸粘膜酵素の各人工消 化液を用いて，マンノオリゴ糖の消化性試験を行った。 その結果を Fig.2に示す．対照としたマルトースの残存 量は, 各消化液の作用で減少する傾向を示したが，マ ンノオリゴ糖は，ほとんどが消化性を示さず，小腸粘 膜まで約 $96 \%$ が残存していた。この結果より，マンノ オリゴ糖は消化されずに大腸まで到達可能であり, 難

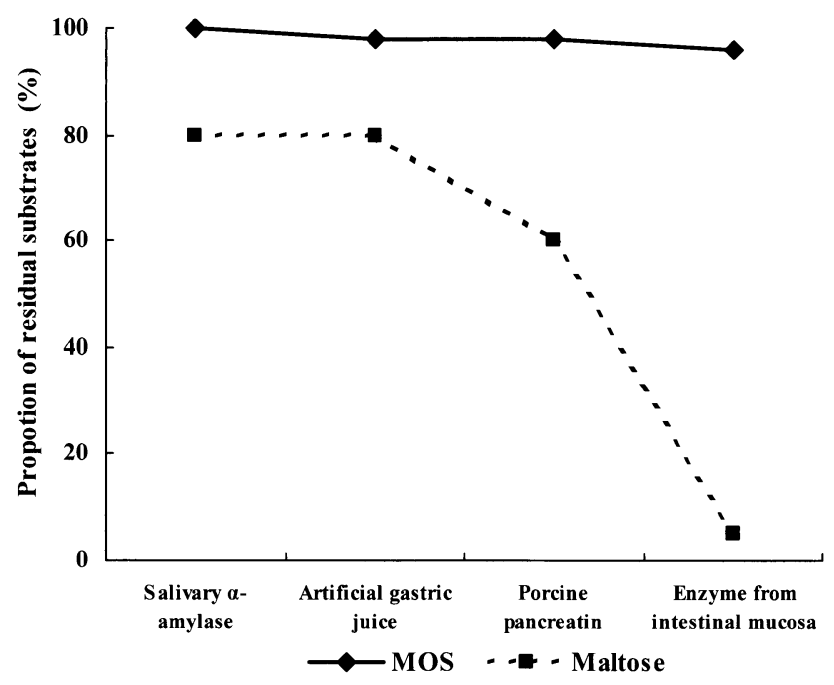

Fig. 2 Digestion of mannooligosaccharides by each artificial digestive enzymes. MOS: mannooligosaccharides. 
消化性のオリゴ糖であることを示した [14].

（2）マンノオリゴ糖の選択資化性

高度精製されたマンノオリゴ糖から $\beta 1,4$ マンノビ オース, $\beta 1,4$ マンノトリオース, $\beta 1,4$ マンノテトラオー スおよび $\beta 1,4$ マンノペンタオースを単離精製して，ヒ 卜由来 19 属 56 種の腸内細菌を用いて選択資化性試験 を行った。 その結果の一部を Table 1 に示す. $\beta 1,4$ マンノビオース, $\beta 1,4$ マンノトリオース, $\beta 1,4$ マンノ
テトラオースおよび $\beta 1,4$ マンノペンタオースは Bifidobacterium. adolescentis, Lactobacillus acidophilus および Lactobacillus gassri にはよく資化される一方で, Bacteroides 属の一部に若干資化されるが，Clostridium perfringens（ウェルシュ菌）およびEscherichia coli（大 腸菌）など，他の菌株に関しては，全く資化されなかっ た。また重合度による資化性に差はなく，マンノペンタ オースまでは同じ資化性を示した。この結果は，マンノ

Table 1 Utilization of intesinal bacteria in human feces.

\begin{tabular}{|c|c|c|c|c|c|c|c|}
\hline Genus & Species & Type No. & Man & $\operatorname{Man} 2$ & Man3 & Man4 & Man5 \\
\hline \multirow[t]{3}{*}{ Bacteroides } & ovatus & CP1129 & ++ & + & + & + & + \\
\hline & thetaiotamicron & $\mathrm{VI}-98$ & ++ & + & + & + & + \\
\hline & vulgatus & B-25 & ++ & - & - & - & - \\
\hline \multirow[t]{6}{*}{ Bifidobacterium } & adolescentis & JB12-5 & ++ & +++ & +++ & +++ & ++ \\
\hline & animalis & JB3-1 & \pm & \pm & - & - & - \\
\hline & bifidum & $\mathrm{AB} 109$ & - & - & - & - & - \\
\hline & breve & IV-19(Riken) & - & - & - & - & - \\
\hline & infantis & $\mathrm{AB} 111$ & - & - & - & - & - \\
\hline & longum & JB8-8 & - & - & - & - & - \\
\hline \multirow[t]{9}{*}{ Clostridium } & cadaveris & XI-10(Riken) & - & - & - & - & - \\
\hline & clostridiiforme & R-14(Riken) & \pm & - & - & - & - \\
\hline & difficile & GAI\#10038 & - & - & - & - & - \\
\hline & innocuum & GAI\#5472 & ++ & - & - & - & - \\
\hline & novyi & GAI\#5614 & - & - & - & - & - \\
\hline & perfringens & B-3-10(Riken) & + & - & - & - & - \\
\hline & septicum & GAI\#7502 & ++ & \pm & \pm & \pm & - \\
\hline & sordellii & GAI\#5612 & - & - & - & - & - \\
\hline & tertium & GAI\#5618 & ++ & - & - & - & - \\
\hline \multirow[t]{2}{*}{ Eubacterium } & aerofaciens & $\mathrm{AB} 403$ & + & - & - & - & - \\
\hline & limosum & $\mathrm{AB} 406$ & - & - & - & - & - \\
\hline \multirow[t]{2}{*}{ Fusobacterium } & mortiferum & GAI\#5442 & - & - & - & - & - \\
\hline & varium & GAI\#5566 & + & - & - & - & - \\
\hline Megamonas & hypermegas & $\mathrm{AB} 301$ & +++ & - & - & - & - \\
\hline Mitsuokella & multiacida & VI-71(Riken) & +++ & - & - & - & - \\
\hline \multirow[t]{2}{*}{ Peptostreptococcus } & asaccharolytica & GAI\#2356 & - & - & - & - & - \\
\hline & prevotii & $\mathrm{AB} 702$ & \pm & - & - & - & - \\
\hline \multirow[t]{2}{*}{ Propionibacterium } & acnes & GAI\#5468 & ++ & - & - & - & - \\
\hline & granulosum & $\mathrm{AB} 502$ & \pm & - & - & - & - \\
\hline \multirow[t]{2}{*}{ Citrobacter } & diversus & CP1249 & ++ & - & - & - & - \\
\hline & freuudii & CP1248 & + & - & - & - & - \\
\hline Enterobacter & cloacae & ATCC23355 & - & \pm & \pm & - & - \\
\hline Enterococcus & faecium & ST-101(Riken) & +++ & \pm & \pm & - & - \\
\hline Escherichia & coli & ATCC25922 & ++ & - & - & - & - \\
\hline Klebsiella & pneumoniae & $\mathrm{CK}-46$ (1) & \pm & - & - & - & - \\
\hline \multirow[t]{5}{*}{ Lactobacillus } & acidophilus & $\mathrm{I}-61$ & +++ & +++ & +++ & ++ & + \\
\hline & casei & ATCC393 & +++ & - & - & - & - \\
\hline & fermentum & L0065 & - & - & - & - & - \\
\hline & gasseri & JCM1131 & +++ & +++ & +++ & +++ & ++ \\
\hline & salivarius & $\mathrm{I}-108$ & +++ & - & - & - & - \\
\hline Morganella & morganii & ME138-1(Deguchi) & + & - & - & - & - \\
\hline \multirow[t]{2}{*}{ Proteus } & mirabilis & ME-14- (2) (Deguchi) & - & - & - & - & - \\
\hline & vulgaris & ATCC13315 & - & - & - & - & - \\
\hline Serratia & marcescens & ATCC 8100 & ++ & - & - & - & - \\
\hline \multirow[t]{3}{*}{ Staphylococcus } & aureus & ATCC25923 & ++ & - & - & - & - \\
\hline & epidermidis & ATCC 12228 & - & - & - & - & - \\
\hline & haemolyticus & CK-6-2(Deguchi) & - & - & - & - & - \\
\hline Streptococcus & pyogenes & ATCC19615 & ++ & \pm & \pm & - & - \\
\hline
\end{tabular}

Man:Mannose, Man2:Mannobiose, Man3: Mannotriose, Man4: Mannotetraose, Man5: Mannopentaose +++ : $\mathrm{pH}<4.5,++: \mathrm{pH} 4.5-5.0,+: \mathrm{pH} 5.0-5.5, \pm: \mathrm{pH} 5.5-6.0,-: \mathrm{pH}>6.0$ 
オリゴ糖が有用菌であるBifidobacterium adolescentis, Lactobacillus acidophilus およびLactobacillus gassri を特 異的に増殖させることができることを示した [12].

(3) ラットの盲腸内細菌叢改善効果

Sprague-Dawly 系ラットを用いて，マンノオリゴ糖 投与における有用性について検討した。 通常飼料およ び5\%マンノオリゴ糖添加飼料をそれぞれ 4 週間投与し た後，盲腸中に含まれるビフィズス菌の占有率および 腸内細菌により産生される短鎖脂肪酸量の測定を行っ

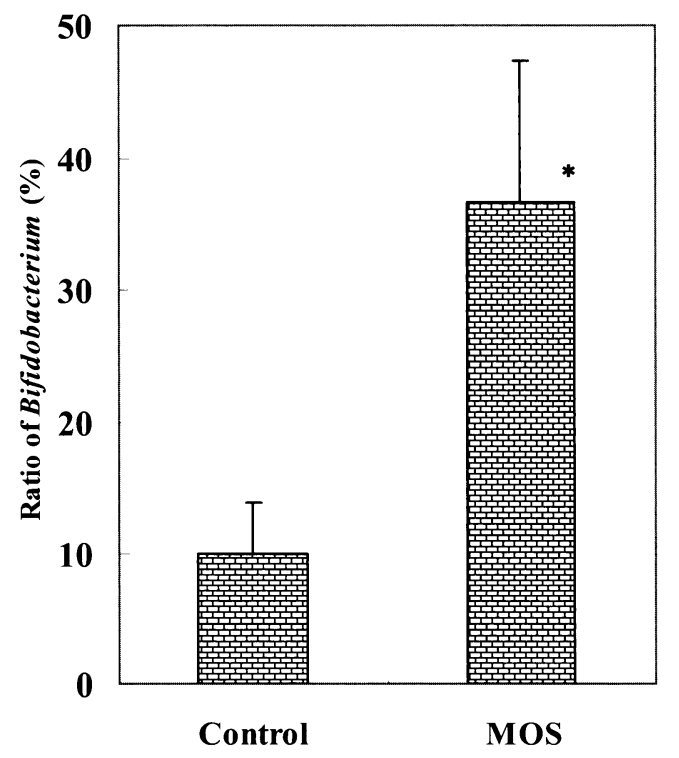

Fig. 3 Ratio of Bifidobacterium in ceca. ${ }^{*}$ : Statistically significant from control $(p<0.05)$. MOS:mannooligosaccharides.

Table 2 Short chain fatty acids (SCFA) in cecal content.

\begin{tabular}{lcc}
\hline & Control & MOS \\
\hline Total SCFA & $13.80 \pm 2.50$ & $34.4 \pm 3.70^{*}$ \\
Acetate & $3.73 \pm 0.47$ & $7.41 \pm 0.39^{*}$ \\
Propionate & $0.89 \pm 0.37$ & $2.7 \pm 0.40^{*}$ \\
n-Butyrate & $1.44 \pm 0.33$ & $3.22 \pm 0.29^{*}$ \\
iso-Butyrate & $2.11 \pm 0.96$ & $5.62 \pm 1.68$ \\
Valerate & $0.15 \pm 0.15$ & nd \\
iso-Valerate & $0.34 \pm 0.22$ & nd \\
\hline
\end{tabular}

Values presented as means and standard errors.

*: Statistically significant from control at $p<0.05$.

MOS: Mannooligosaccharides. nd: means not detected.
た。盲腸内細菌叢における Bifidobacterium の占有率の 結果について Fig.3に示す. マンノオリゴ糖投与群は, 通常飼料群と比べて有意に増加しており, 約 3 倍の増 加量であった. また, 腸内細菌の生成物である短鎖脂 肪酸の産生量について，マンノオリゴ糖投与は，通常 飼料を投与したラットよりも有意に増加した（Table 2).これらの結果は，マンノオリゴ糖の投与が盲腸内 のBifidobacterium を増加させ, 短鎖脂肪酸の産生を増 加させることを示した [15].

(4) 臨床試験による整腸効果の確認

マンノオリゴ糖をヒトに摂取させた場合のプレバイ オティクスとしての有用性について確認するため, 臨 床試験を行った。 マンノオリゴ糖の精製パウダーの 1 日摂取量は， $1.0 \mathrm{~g}$ および $3.0 \mathrm{~g}$ に設定し，試験期間を 2 週間ずつの二重盲検試験を実施した。各試験期間中の 排便日数および排便回数の結果を Table 3 示す. 排便日 数では，マンノオリゴ糖の摂取量が増加するごとに上 昇傾向を示し，1 日摂取量 $3.0 \mathrm{~g}$ で対照より有意に上昇 した。 また，排便回数も同様の傾向を示し，マンノオ リゴ糖の摂取量が増加するごとに上昇傾向があり，1日 摂取量 $1.0 \mathrm{~g}$ および $3.0 \mathrm{~g}$ で対照より有意に上昇した. Bifidobacterium の占有率では，マンノオリゴ糖の 1 日 摂取量が $1.0 \mathrm{~g}$ および $3.0 \mathrm{~g}$ で有意に増加して, 対照と 比べて約 3 倍の上昇を示した（Fig. 4). これらの結果, マンノオリゴ糖 1 日摂取量 $1.0 \mathrm{~g}$ で Bifidobaterium の上 昇を伴う排便状態の改善が確認された [16].

\section{5. 整腸効果を訴求したマンノオリゴ糖含有製品の 開発}

これら一連の研究により，マンノオリゴ糖がプレバ イオティクスとしての機能性を有していることを確認 し，我々はマンノオリゴ糖を配合した製品の開発に着 手した。 マンノオリゴ糖の特性から，様々な食品形態 への応用が可能であり，これまでにミックスコーヒー [17]，インスタントコーヒー[17], 液体コーヒー [18,19] およびカフェオレ（牛乳入り液体コーヒー）[19,20]な ど，幅広く応用されている。これら開発された全ての 製品は，厚生労働省より特定保健用食品として表示許 可を取得している.

Table 3 Effects of mannooligosaccharides administration on the defecating conditions.

\begin{tabular}{lccc}
\hline & Before intake & MOS 3 g/day & MOS 1 g/day \\
\hline Defecation days per week & $4.5 \pm 0.6$ & $6.0 \pm 0.5^{*}$ & $5.5 \pm 0.3^{*}$ \\
Defecation frequency per week & $4.9 \pm 0.7$ & $8.0 \pm 0.7^{*}$ & $6.8 \pm 0.6^{*}$ \\
\hline
\end{tabular}

Values presented as means and standard errors.

*: Statistically significant from before intake at $p<0.05$.

MOS: Mannooligosaccharides. nd: means not detected. 


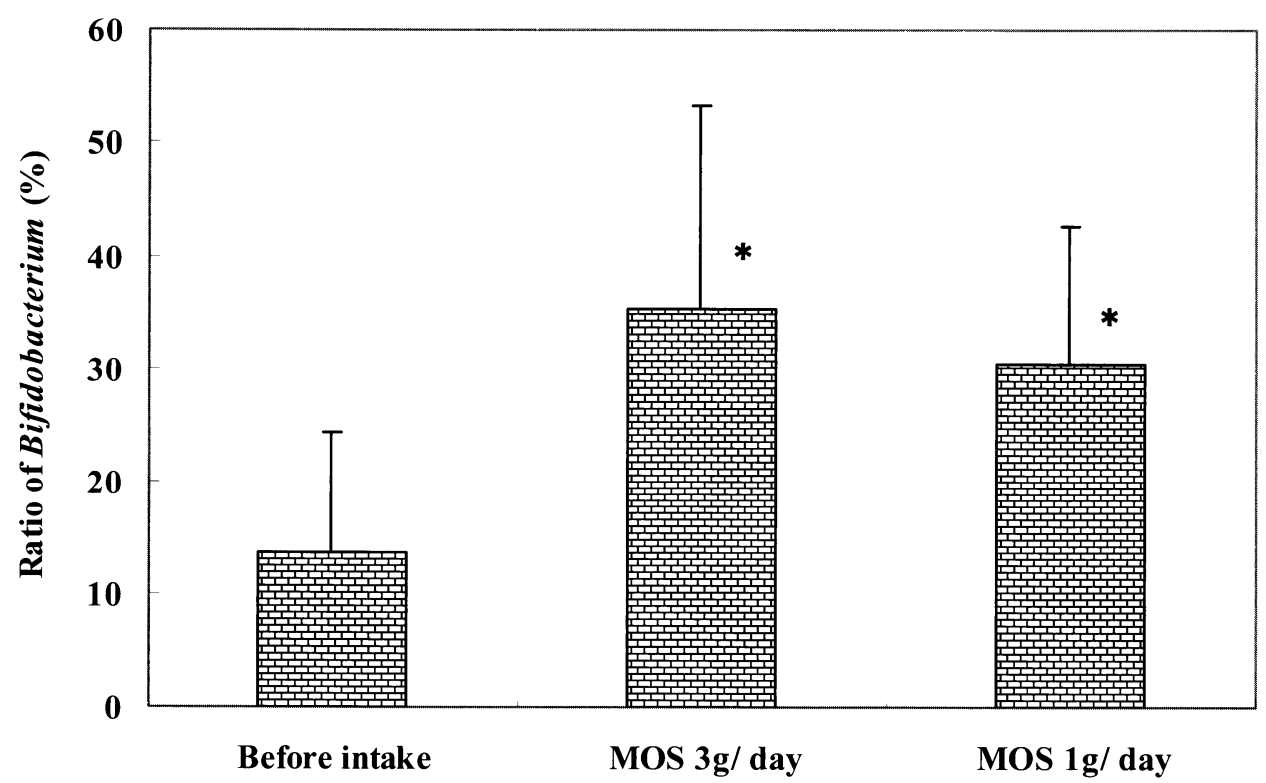

Fig. 4 Influence of mannooligosaccharides intake on the occupancy of fecal Bifidobacterium.

${ }^{*}$ : Statistically significant from before intake $(p<0.05)$.

\section{6. 体脂肪低減作用}

マンノオリゴ糖の機能性について, 我々は, 整腸効 果に続いてさまざまな評価を進めている。これまでに ミネラル吸収促進作用, 血清脂質改善作用および血糖 值調節作用など，新たな可能性が見出されている。 そ の中でマンノオリゴ糖の更なる機能性として，我々は 体脂肪低減作用について詳細な検討を開始した。

(1) 動物試験に打ける抗肥満作用

遺伝的過食を発現する (ZUC) $-f a / f a$ ラットに，マン ノオリゴ糖含有飼料を 8 週間にわたって投与したとき の, 肝臓への影響について検討した。 その結果，マン ノオリゴ糖投与群は, 肝臟の重量, 肝臟中の中性脂肪 およびコレステロールが対照群と比べて有意に減少す ることが確認された（Table 4） [21]．また, Wistar ラッ トにマンノオリゴ糖を配合した脂質溶液を経口投与し た後，門脈血中の脂肪酸濃度を測定した。その結果， マンノオリゴ糖投与群は, 対照群と比べて脂肪酸濃度 の上昇を抑制することを確認した（Fig. 5）[22].

(2) 臨床試験による体脂肪低減作用の確認

マンノオリゴ糖の撕取により，体脂肪が低減するこ とを以下の臨床試験で確認した. $25 \mathrm{~kg} / \mathrm{m}^{2} \leqq \mathrm{BMI}<30$ $\mathrm{kg} / \mathrm{m}^{2}$ の成人男女 30 名を 2 群に分け，マンノオリゴ糖 を $3.0 \mathrm{~g} /$ 日含有した液体コーヒーを 12 週間にわたって 掑取させた後, CT スキャンを用いて腹部脂肪面積を測 定した。その結果，マンノオリゴ糖の摂取により腹部 脂肪横断面積の有意な減少が確認された [23]. また被 験者の人数を増やし 48 名で同様の臨床試験を実施した [24]．この試験では BMI $25 \mathrm{~kg} / \mathrm{m}^{2}$ 以上のヒトが対象と
Table 4 Effects of mannooligosaccharides administration on the liver.

\begin{tabular}{lcc}
\hline & Control & MOS \\
\hline Weight \% & $4.06 \pm 0.27$ & $3.12 \pm 0.15^{* *}$ \\
Triglyceride $(\mathrm{mg} / \mathrm{g})$ & $307.7 \pm 17.4$ & $216.6 \pm 20.4^{*}$ \\
Total cholesterol $(\mathrm{mg} / \mathrm{g})$ & $7.49 \pm 0.45$ & $5.48 \pm 0.26^{*}$ \\
\hline
\end{tabular}

Values presented as means and standard errors.

*, ** : Statistically significant from control at $p<0.05$ and $p<0.01$, respectively.

MOS: Mannooligosaccharides.

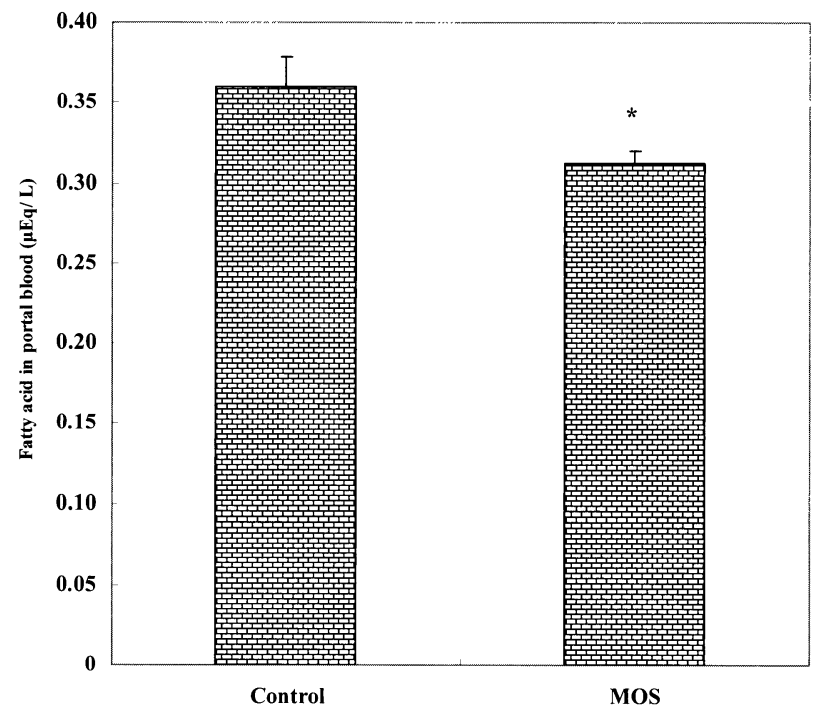

Fig. 5 Effect of mannooligosaccharides on fatty acid level in portal blood." : Statistically significant from before intake $(p<0.05)$. MOS: mannooligosaccharides. 
Table 5 Effects of mannooligosaccharides ingestion on abdominal fat areas.

\begin{tabular}{|c|c|c|c|}
\hline & & 0 week & 12 weeks \\
\hline \multirow[t]{2}{*}{ Total fat area $\left(\mathrm{cm}^{2}\right)$} & Placebo & $279.1 \pm 12.0$ & $283.2 \pm 12.6$ \\
\hline & MOS & $282.0 \pm 9.8$ & $262.6 \pm 9.7^{* *}$ \\
\hline \multirow[t]{2}{*}{ Difference From $0 \mathrm{~W}$} & Placebo & & $4.1 \pm 5.5$ \\
\hline & MOS & & $-19.4 \pm 6.1 \dagger \dagger$ \\
\hline \multirow[t]{2}{*}{ Subcutaneous fat area $\left(\mathrm{cm}^{2}\right)$} & Placebo & $188.1 \pm 12.0$ & $190.7 \pm 12.4$ \\
\hline & MOS & $195.5 \pm 13.2$ & $184.9 \pm 12.1^{*}$ \\
\hline \multirow[t]{2}{*}{ Difference From $0 \mathrm{~W}$} & Placebo & & $2.6 \pm 5.2$ \\
\hline & MOS & & $-10.6 \pm 5.0$ \\
\hline \multirow[t]{2}{*}{ Visceral fat ares $\left(\mathrm{cm}^{2}\right)$} & Placebo & $91.0 \pm 7.9$ & $93.8 \pm 8.0$ \\
\hline & MOS & $91.1 \pm 6.0$ & $83.2 \pm 6.1^{* *}$ \\
\hline \multirow[t]{2}{*}{ Difference From $0 \mathrm{~W}$} & Placebo & & $2.8 \pm 3.4$ \\
\hline & MOS & & $-7.9 \pm 2.2 \dagger \dagger$ \\
\hline
\end{tabular}

Values presented as means and standard errors.

$*, * *$ : Statistically significant from before ingestion 0 week at $p<0.05$ and $p<0.01$, respectively. $\dagger \uparrow$ : Statistically significant from placebo at $p<0.01$.

MOS: Mannooligosaccharides.

して，マンノオリゴ糖を $3.0 \mathrm{~g} /$ 日含有した液体コーヒー を 12 週間にわたって摂取させた後，CT スキャンを用 いて腹部脂肪面積を測定した。その結果，マンノオリ ゴ糖の㠌取は，掑取前およびプラセボ摄取群と比べて 腹部皮下脂肪面積, 腹部内臓脂肪面積および腹部全脂 肪面積ともに有意に低下した（Table 5）[24]．別の臨 床試験では，成人男性 8 名に高脂肪食とともにマンノ オリゴ糖を摂取させた後, 血液中の中性脂肪濃度を経 時的に測定したところ，マンノオリゴ糖の掑取が脂肪 の吸収を抑制することを確認し [25]，更にマンノオリ ゴ糖配合コーヒ一飲料の掑取が，排泄される脂質を増 加させることも確認している $[26,27]$

\section{7. 体脂肪低減効果を訴求したマンノオリゴ糖 含有製品の開発}

マンノオリゴ糖の摄取は，中性脂肪の吸収抑制によ る排泄脂質の上昇作用等により，余剩に蓄積されてい た脂肪の代謝を高め, 体脂肪低減に効果を発揮するこ とが示唆された。体脂肪低減作用を訴求した製品開発 は，液体コーヒー $[23,24]$ およびインスタントコーヒー [28]に応用が検討され，これらの製品は特定保健用食 品として表示許可を取得した，関与成分がオリゴ糖で あることおよび製品形態がコーヒーであることは，体 脂肪関連の特定保健用食品として初めての表示許可で あった。

\section{8. 今後の可能性}

マンノオリゴ糖を関与成分とした特定保健用食品は,
整腸作用で 12 品目, 体脂肪低減作用で 7 品目が許可を 受けている（2007 年 10 月現在）。これらの既許可品は, 全てコーヒーの食品形態である。しかし，マンノオリ ゴ糖の特性を考慮した場合，味および品質を変えるこ となく幅広い食品に応用することが可能であり，更な る用途開発が期待される。また，マンノオリゴ糖の機 能性は，整腸作用および体脂肪低減作用以外にも，抗 アレルギー作用 [29] や血圧上昇抑制作用 [30] など,様々 な可能性を秘めている素材であり, 今後の研究が待た れる.

\section{謝辞}

本研究は，多くの大学と公的機関のご協力を頂きな がら，味の素ゼネラルフーヅ株式会社商品・技術開発 研究所で行われたものです．直接ご指導とご助言を頂 きました味の素ゼネラルフーヅ株式会社 理事 商品・技 術開発研究所長 井村直人博士をはじめとして多くの関 係者の方々に厚く御礼申し上げます。マンノオリゴ糖 の整腸効果の評価を行うにあたり，多大なご指導，ご 助言を頂いた昭和女子大学飯野久和教授に深謝いたし ます。また，マンノオリゴ糖の体脂肪低減効果の評価 を行うにあたり，数々のご助言，ご指導頂いた京都大 学大東肇名誉教授，河田照雄教授，安達修二教授，熊 本県立大学奥田拓道教授，韓立坤博士，マンノオリゴ 糖の他の機能性についてご評価頂いた北里大学小宮山 宽機教授，林正彦准教授（現いわき明星大学教授）に 心より感謝いたします，さらに，マンノオリゴ糖の構 造解析にご尽力頂いた岐皁大学木兽真教授，石田秀治 教授に感謝いたします。また，マンノオリゴ糖の分析 
方法の設定にあたってご助言頂いた国立健康・栄養研 究所食品分析プロジェクトリーダー萩原清和博士に感 謝いたします。

\section{参 考 文 献}

[1] 若澤秀幸，高橋和彦，望月一男; コーヒー粕の施用が作物 生育と土堙理化学性に及ぼす影響ーコーヒー粕の土壤試 施用と堆肥化条件（第 1 報）一。 日本土塞肥料科学雑誌, 69, 1-6 (1998).

[2] J. V. Higdon, B. Frei; Coffee and health: A review of recent human research. Crit. Rev. Food. Sci. Nutr., 46, 101-123 (2006).

[3] B. A. Oyofo, J. R. DeLoach, D. E. Corrier, J. O. Norman, R. L. Ziprin, H. H. Mollenhauer; Prevention of Salmonella typhimurium colonization of broilers with D-mannose. Poult Sci., 68, 1357-1360 (1989).

[4] C. W. Parks, J. I. Grimes, P. R. Ferket, A. S. Fairchild; The effect of mannanooligosaccharides, bambermycins, and virginiamycin on performance of large white male market turkeys. Poult. Sci., 70, 718-723 (2001).

[5] 戸枝一喜, 保获美佳; 大豆種皮からの酵素処理によるマン ノース，マンノオリゴ糖の製造方法. 秋田県総合食品研 究所報告.

[6] 渡部一穂; ビフィズス因子としてのオリゴ糖. 実践女子大 学家政学部紀要, 29, 1-9 (1992).

[7] S. Saittagaroon, S. Kawakishi, M. Namiki; Characterisation of polysaccharides of copra meal. J. Sci. Food. Agric., 34, 855-860 (1983).

[8] 日下部功；キシロビオース，マンノオリゴ糖の生産技術. 日本農芸化学会誌，63，1141-1143（1989）。

[9] 橋本揚之助, 福本寿一郎; コーヒ一豆の酵素処理に関する 研究 (第 1 報) Rhizopus niveus のマンナナーゼの精製と そのコーヒーマンナンに対する作用. 日本農芸化学会誌， 43, 317-322 (1969)

[10] 橋本揚之助; コーヒ一豆の酵素処理に関する研究 (第 4 報) マンナナーゼによるコーヒーマンナンおよびコーヒ一豆 の分解に及ぼす塩濃度の影響. 日本農芸化学会誌，44, 287-292 (1970).

[11] A. Sachslehner, G. Foidl, N. Foidl, G. Gübitz, D. Haltrich; Hydrolysis of isolated coffee mannan and coffee extract by mannanases of Sclerotium rolfsii. J. Biotech. 80, 127-134 (2000).

[12] 浅野一朗, 中村保幸, 星野宏充, 青木敬司, 藤井繁 佳, 井村直人, 飯野久和; コーヒーマンナン由来マン ノオリゴ糖の腸内細菌資化性. 日本農芸化学会誌, 75, 1077-1083 (2001).

[13] 藤井繁佳, 熊王俊男; “機能性糖質素材の開発と食品 への応用”，井上國世編，シーエムシー出版，2005, pp.135-144

[14] I. Asano, K. Hamaguchi, S. Fujii, H. Iino; In vitro digestibility and fermentation of mannooligosaccharides from coffee mannan. Food Sci. Technol. Res., 9, 62-66 (2003).

[15] I. Asano, Y. Ikeda, S. Fujii, H. Iino; Effects of mannooligosacchaieds from coffee mannan on microbiota and short chain fatty acids in rat cecum. Food Sci. Technol. Res., 10, 273-277 (2004).

[16] I. Asano, M. Umemura, S. Fujii, H. Hoshino, H. Iino; Effects of mannooligosaccharides from coffee mannan on fecal microflora and defecation in healthy volunteers. Food Sci. Technol. Res., 10, 93-97 (2004).

[17] M. Umemura, S. Fuji, I. Asano, H. Hoshino, H. Iino; Effect of coffee mix drink containing mannooligosacchairdes from coffee mannan on defecation and fecal microbiota in healthy volunteers. Food Sci. Technol. Res., 10, 195-198 (2004).

[18] T. Kumao, S. Fujii, K. Ozaki, K. Mutoh, K. Nakamuro, T Matsushima, H. Iino; Effects of liquid coffee containing mannooligosaccharides from coffee mannan on defecation and fecal microbiota in healthy volunteers. Health Sci., 21, 137-146 (2005).

[19] 熊王俊男，藤井繁佳，尾崎和人，武藤勝仁，中室賢一，松 島俊行，飯野久和；コーヒー豆マンノオリゴ糖入り液体 コーヒ一飲料が健康正常人の排便状態および腸内細菌叢 に及ぼす影響. Health Sci., 21，69-76（2005）。

[20] 熊王俊男，藤井繁佳，尾崎和人，武藤勝仁，中室賢一，松 島俊行，飯野久和；コーヒー豆マンノオリゴ糖配合牛乳 入りコーヒー飲料が健康正常人の排便状態および腸内細 菌叢に及ぼす影響. FFI Journal, 209, 1112-1116（2004）.

[21] 熊王俊男，藤井繁佳，尾崎和人，高尾和泉 ; コーヒ一豆 マンノオリゴ糖配合飼料長期投与が $(Z U C)-f a / f a$ 系 ラットの肝臓中脂質に及ぼす影響。医学と薬学， 54, 505-509 (2005).

[22] 高尾和泉，韓立坤，石井朝子，藤井繁佳，奥田拓道；ラッ 卜における血中脂肪酸および血中中性脂肪に及ぼすコー ヒー豆マンノオリゴ糖の影響. 医学と薬学， 56 , 57-62 (2006)

[23] 浅野一朗，藤井繁佳，尾崎和人，竹原功，矢野夕機，福原 育夫 ; コーヒー豆マンノオリゴ糖を含むコーヒー飲料の 長期摂取がヒト体脂肪に及ぼす影響。日本食品工学会誌, 6, 133-141 (2005)

[24] 浅野一朗，藤井繁佳，金子正行，竹原功，福原育夫;マン ノオリゴ糖配合コーヒー飲料摂取による体脂肪低減作用. 医学と薬学， 55, 93-103 (2006).

[25] 熊王俊男, 藤井繁佳, 尾崎和人，高尾和泉；ヒトにおける コーヒー豆マンノオリゴ糖の単回摂取が血液中中性脂肪 に及ぼす影響．日本食品工学会誌，6，301-304（2005）。 
[26] T. Kumao, S. Fujii; Mannooligosaccharides blended coffee beverage intake increases the fat level in feces. J. Health Sci., 52, 329-332 (2006).

[27] T. Kumao, S. Fujii, A. Asakawa, I. Takehara, I. Fukuhara; Effect of coffee drink containing mannooligosaccharides on total amount of excreted fat in healthy adults. J. Health Sci., 52, 482-485 (2006).

[28] 熊王俊男，藤井繁佳，竹原功，福原育夫；マンノオリゴ糖 を配合したインスタントコーヒー拱取による体脂肪低減 作用. 薬理と治療， 35，673-679（2007）.

[29] K. Ozaki, S. Fujii, M. Hayashi; Effect of dietary mannooligosaccharides on the immune system of ovalbumin-sensitized mice. J. Health Sci., 53, 766-770 (2007)

[30] I. Hoshino-Takao, S. Fujii, A. Ishii, H. Li-kun, H. Okuda,

T. Kumao; Effects of mannooligosacchurides from coffee mannan on blood pressure in Dahl salt-sensitive rat. J. Nutri. Sci. Vitaminol. in press.
要

旨

世界的にみて，コーヒーは最もポピュラーな飲料の 1 つである. 近年, 多くの疫学研究により，コーヒーの 飲用が様々な病気の予防に関与していることが示唆さ れており，注目されつつある.コーヒーには幾つかの 生理活性物質が含まれており，生体に有用な効果を及 ぼすことが知られている。その中で我々は，コーヒー 抽出粕を熱加水分解することによって得られるマンノ オリゴ糖（MOS）に着目した. MOS は感染症予防など で注目されているマンノースを構成糖としており, 様々 な機能が期待されたが，その有効性については殆ど解 明されていなかった。そこでMOSの機能性評価および 応用研究を開始した。最初に，MOSの整腸作用につい て in vitro, 動物試験および臨床試験でその機能性を確 認した．次に，動物試験および臨床試験により MOS が 小腸における脂質の吸収を抑制して，体脂肪の低減作 用を有していることを確認した。これらの知見は, MOS入りのコーヒー製品の開発に応用され，特定保健 用食品として上市された。 